Grafe, Regina. 2011. Distant Tyranny: Markets, Power and Backwardness in Spain, 1650-1800. Princeton, NJ: Princeton University Press.

Gutiérrez, Gustavo. (1971) 1973. A Theology of Liberation. Edited and translated by Caridad Inda and John Eagleson. Maryknoll, NY: Orbis.

Mariátegui, José Carlos. 1974. Seven Interpretive Essays on Peruvian Reality. Austin: University of Texas Press.

Márquez, Iván. 2008. Contemporary Latin American Social and Political Thought. New York: Rowman \& Littlefield.

Mignolo, Walter. 1999. Local Histories/Global Designs. Princeton, NJ: Princeton University Press.

Pagden, Anthony. 1998. Spanish Imperialism and the Political Imagination. New Haven, CT: Yale University Press.

Reid Andrews, George. 2004. Afro-Latin America, 1800-2000. Oxford: Oxford University Press.

Schutte, Ofelia. 1993. Cultural Identity and Social Liberation in Latin American Thought. New York: SUNY Press.

Unger, Roberto. 1997. Politics: The Central Texts, Theory Against Fate. Edited by Cui Zhiyuan. New York: Verso.

Vasconcelos, Jose. 1997. La Raza Cosmica. Baltimore, MA: Johns Hopkins University Press.

von Vacano, Diego. 2011. The Color of Citizenship: Race, Modernity and Latin American/Hispanic Political Thought. Oxford: Oxford University Press.

Zea, Leopoldo. 1991. The Role of the Americas in History. New York: Rowman \& Littlefield.

\section{Law and Political Thought}

In the modern period, the most original and influential theories about law and politics were developed in connection with a set of far-reaching, interrelated questions about the definition of law, the purpose of law, the relationship between law and morality, and the existence of natural law and natural rights.

\section{Montesquieu}

Charles-Louis de Secondat, Baron de La Brède et de Montesquieu (1689-1755), published The Spirit of the Laws in 1748 . In this widely read and highly influential work (it appeared in 22 editions within 18 months after its first publication), Montesquieu defines laws as "the necessary relations deriving from the nature of things." Laws are both the relations that exist between God and created beings and the relations of these created beings to one another.
For Montesquieu, it is possible to discern a uniformity in the relations between things, despite their wide diversity. Thus, although one body is capable of moving another body in various ways, such motion will always be in accordance with the relations of mass and velocity. A similar kind of uniformity in the midst of diversity can be found in human affairs. Even before humans make their own positive laws, there exist "possible relations of justice" that determine which actual relations between humans are just and which are unjust. For Montesquieu, there are thus laws of nature or natural laws that are grounded in the very nature of things and that underlie true "relations of fairness" as they exist apart from any positive or human-made laws, and apart from the will of any sovereign.

Although affirming the existence of natural law, Montesquieu differs from previous thinkers who held that one or another form of government was the "most natural" for human beings. For Montesquieu, what is "most natural" is not that which is "most common" or "most basic" but what is most in accord with a thing's nature or its internal principle of activity. Just as individual things have their own natures, so too a people or a nation can be said to have a nature or "character" or "general spirit" of its own. The general spirit of a people emerges in connection with a wide variety of particular conditions pertaining to that people, including their climatic and geographical situation, their way of life, their degree of liberty, their religion, their level of wealth, the size of their population, their modes of commerce, and their mores and manners. When contemplating acts of legislation, says Montesquieu, legislators should not be guided by abstract, rationalistic ideas about justice but by the general spirit of the people for whom the legislation is intended. Law is most effective, after all, when it is least coercive and most suited to a people's "natural genius." Furthermore, legislators should not try to correct all the mores and manners of a people but only those that are manifestly unjust or harmful. Even when some mores and manners stand in need of correction, it is best if political leaders aim to correct them, not by relying on the coercive force of the law but by appealing to other mores and manners already recognized by the people.

One of Montesquieu's best-known contributions to legal and political theory is his argument for a "separation of powers" within the state. 
Montesquieu identifies three possible kinds of powers within the state: the legislative power, the executive power over the things depending on the right of nations (or simply "the executive power"), and the executive power over the things depending on civil right (or simply "the judicial power"). If political liberty is to be preserved, Montesquieu argues, then these three powers must be vested in different individuals or different bodies, each acting independently of the other two. If individuals are to have political liberty, says Montesquieu, then the government and laws must be arranged so that no citizen stands in fear of any other citizen. Such becomes impossible, however, when two or more of the state's powers are vested in a single individual or in a single body.

Montesquieu's Spirit of the Laws was praised by radical progressives such as Voltaire (who appreciated Montesquieu's observations about religious diversity and tolerance) but also by traditionalist conservatives such as Edmund Burke (who shared Montesquieu's skepticism about affecting social change through coercive legal means). The influence of Montesquieu's thought regarding the separation of powers is readily discernible in the Instruction of Catherine the Great of Russia, in the Federalist Papers (especially nos. 47 through 51), in the American Constitution, and in the French Declaration of the Rights of Man.

\section{William Blackstone}

The work of William Blackstone (1723-80) is important not so much for its originality as a piece of legal theory as for its originality as a work of systematization. Blackstone's four-volume work, Commentaries on the Laws of England, was first published in England between 1765 and 1769 and then in the United States between 1771 and 1772. The Commentaries gave systematic form to a vast range of previously disconnected legal questions, showing how almost every aspect of English law could be analyzed and explained through the basic principles of a "rational science" of law. This "rational science" was divided into four parts, focusing on "the rights of persons" (Book I); "the rights of things," by which Blackstone meant the rights that people can have in things (Book II); "private wrongs," including torts (Book III); and "public wrongs," including crimes against other citizens, against God, and against religion (Book IV).
Blackstone defines law as "a rule of action dictated by some superior being." As applied to human action, laws are the precepts by which humans are commanded how to regulate their behavior. For Blackstone, human beings are obliged to obey the laws given to them by God, for an inferior being is inevitably obliged to follow the rules of conduct given to it by the superior being on which it depends. But human beings are not only obliged to obey the will of God, they are naturally inclined to do so as well. This is because God, in His infinite wisdom and goodness, constituted human beings so that they would need no inducement to follow the law of nature other than their own self-love, which is the "universal principle" of human action. According to Blackstone, the rule of obedience for all human action can be reduced to one precept, which constitutes the foundation of all ethics or natural law: "[M]an should pursue his own true and substantial happiness" (1765, Vol. I, 41).

For Blackstone, the precepts of the natural law are universally binding on all human beings, regardless of time or place. All positive, or human-made, laws derive their force and authority from the natural law; human laws that are contrary to the natural law can have no validity. If humans were always clear and unprejudiced in their reasoning, they could know how to act by relying on their natural reason and their natural inclinations alone. But since humans are prone to ignorance and error, they need the further guidance of revealed or divine law, which God has provided through the scriptures. But the natural law and the divine law, on their own, are insufficient for guiding human conduct. This is because humans are neither self-sufficient nor courageous enough to live entirely on their own; they need to live in society with one another. Since it is impossible for all human beings to be united within a single, comprehensive society, they end up forming a multiplicity of separate, but interacting, states. Accordingly, there arises not only the need for municipal law or civil law (which governs the relations prevailing within a single state), but also the need for a "law of nations" or jus gentium (which governs the relations of different states to one another).

Municipal or civil law, says Blackstone, is a rule of civil conduct prescribed by the supreme power within a state. For Blackstone, the primary aim of human society and thus of municipal law is to protect individuals in their enjoyment of the "absolute 
rights" they possess simply in virtue of the immutable laws of nature. These absolute rights include the rights to personal security, to personal liberty, and to personal property. No human legislature has the power to abridge or destroy these rights, says Blackstone, unless their possessor has committed an act that amounts to a forfeiture of such rights. A secondary aim of human society and thus of municipal law is to protect individuals in their enjoyment of "social" or "relative" rights (e.g., the right to trial by jury), which result from and are posterior to the formation of states and societies.

The municipal law of England can be subdivided into two kinds: "the unwritten common law" and "the written or statute law." Because written law is expressed in general and not particular terms, it follows that no written law can fully anticipate the concrete circumstances under which it might be applied. Thus, the determination of what a written law actually commands in some particular circumstance will require some recourse to the rationale or justification behind the law. Since only intelligent beings can discern when and how the law's rationale might apply, "it is necessary that when the general decrees of the law come to be applied to particular cases, there should be somewhere a power vested of defining those circumstances" for applying the law (1765, Vol. I, 62). Thus, there arises the need for judges, who are authorized to decide cases in light of "equity" by taking into consideration the particular circumstances surrounding individual cases. If the rationale or justification behind a written law ceases to apply, says Blackstone, then "the law also ceases with it" (Commentaries, 1767, Vol. III, 219; 1765, Vol. I, 61). For Blackstone, the unwritten "common law," as embodied in the understandings, practices, and customs of judges, can never be supplanted by a system of written law or "statute law." When deciding cases in light of equity, Blackstone goes on to argue, judges generally should follow past precedents; however, judges may disregard previous decisions when they are manifestly absurd or unjust. This is not because such previous decisions are instances of bad law; rather, it is because-being contrary to reason or justice-they are not law at all.

Blackstone's Commentaries were exceedingly influential at the time of the American founding, and they were regularly cited by those in favor of ratifying the American Constitution (e.g., by Alexander Hamilton, in Federalist nos. 69 and 84) as well as by those opposed to ratification (e.g., by Patrick Henry, who argued, in reliance on Blackstone, that the Constitution should provide for jury trials in civil cases). Blackstone's Commentaries remained a staple of Anglophone legal education for the next 150 years.

\section{Jeremy Bentham}

In 1763, Jeremy Bentham (1748-1832) attended the Oxford University lectures given by Blackstone that were later to become part of the latter's Commentaries on the Laws of England. But unlike Blackstone, who sought to explain and justify English law, Bentham was interested primarily in critique and reform. And unlike both Montesquieu and Blackstone, whose main contributions to legal thought can be found in individual works, Bentham disseminated his key ideas about law and politics through a vast collection of disparate writings, including A Fragment on Government (1776), A Defence of Usury (1787), Introduction to the Principles of Morals and Legislation (1789), An Essay on Political Tactics (1791), Panopticon, or the Inspection House (1787), Emancipate Your Colonies (1793), Catechism of Parliamentary Reform (1809), Punishments and Rewards (1811), A Table of the Springs of Action (1815), Chrestomathia (1816), Church of Englandism and Its Catechism Examined (1818), Radicalism is Not Dangerous (1819-20), and A Treatise on Judicial Evidence (1825). A summary of Bentham's criticisms of Blackstone can be found in his Fragment on Government, which is a shortened version of a more extensive critique, Comments on the Commentaries, published posthumously in 1928 .

What we call law, says Bentham, is not grounded in the nature of things or in the divine ideas of an all-benevolent God; it is grounded instead in the will of a sovereign (whether this be an individual or a group) that has the power to command its subjects to act in certain ways, and to induce obedience in its subjects by means of punishments and rewards. For Bentham, the purpose of human law cannot be to protect any "natural" order of justice or "natural" rights as they allegedly exist apart from positive laws and apart from the will of a sovereign. This is because there are no such things as "natural" rights or "natural" justice in the first place. According to Bentham, a "right" is nothing other than an actual 
"security" enjoyed by someone under the protection of some more powerful person or body (such as the sovereign). It follows from this that there is no such thing as a right that is not an enforceable right; and no such thing as justice that is not enforceable justice. For Bentham, then, the positive law does not protect preexisting rights or enforce preexisting duties that persons allegedly have in a state of nature or as a matter of natural right; on the contrary, it is the positive law that brings into existence all the rights and duties that persons have in the first place. The ideas of law, offense, right, and obligation, says Bentham, "are born together" and are inseparably connected.

According to Bentham, proponents of "natural law" jurisprudence (including Blackstone) systematically failed to distinguish between "expositorial" (or merely descriptive) jurisprudence and "censorial" (or evaluative) jurisprudence. As a result, they also failed to distinguish between the law as it is and the law as it should be. On account of these confusions, "natural law" thinkers were led to the erroneous view that law, in order to exist at all, must be in accord with reason and justice and, conversely, that supposedly "bad" laws-being contrary to reason and justice-could not really exist as laws at all. Against such "natural law" reasoning, Bentham argued that it is obvious that "bad" laws can exist. For a law, after all, is nothing other than the command of a sovereign backed by the threat of force. It is obvious that a command can be issued, and those subject to it can be induced to obey, even if there is nothing "reasonable" or "just" about the command being issued. By arguing that the existence of law is one thing and its moral merit is another (or that there is "no necessary connection" between law and morality), Bentham laid the theoretical groundwork for what has since come to be known as modern "legal positivism."

Bentham opposed "natural law" reasoning, not only because he regarded it as deeply confused as a matter of theory, but he also believed that it supported perniciously antireformist consequences in the realm of practice. If bad law is no law at all, as the "natural law" theorists held, then it becomes difficult to see how actual existing laws could be "bad" and thus in need of reform. For Bentham, it is only by acknowledging that "bad" laws can exist that we will be in a position to begin reforming them. Furthermore, the question of how bad laws should be reformed is not to be settled by reference to an empty, abstract, speculative account of "natural law"; instead, it is to be settled by reference to a readily accessible and easily understandable standard of right and wrong, namely, the principle of utility. According to this principle, an action is right to the extent that it tends to produce pleasure or happiness and wrong to the extent that it tends to produce pain or unhappiness. For Bentham, the actions of all individual and all legal regimes are to be measured and judged in accordance with the principle of utility or "the greatest happiness principle." The guiding purpose of the law should be nothing other than to promote social welfare or utility or "the greatest happiness for the greatest number."

Bentham's commitment to the principle of utility led him to hold that legal punishments could be justified only on the grounds that they incentivize good behavior and deter bad behavior in those who are subject to the law. As a result, he argued that legal punishment was not for the sake of retribution, and he sought to reform many of England's often-cruel penal practices that had been based on retributivist ideas about punishment. Bentham's belief in the principle of utility also led him to argue in favor of replacing the unwritten "common law" of England with a fully written, codified system of statutory law. Because the "common law" was unwritten and depended so heavily on the unpredictable, discretionary rulings of judges, it failed to provide legal subjects with sufficient advance guidance about how they should conduct themselves; and when the law fails in this way, he noted, it cannot properly serve to incentivize good behavior and deter bad behavior. Bentham famously derided England's regime of unwritten, judge-made "common law" as a regime of arbitrary, ex post facto law-making that was more suited to dogs than to human beings:

When your dog does anything you want to break him of, you wait till he does it, and then you beat him for it. This is the way you make laws for your dog: and this is the way the judges make law for you and me. They won't tell a man beforehand what it is he should not do (1843, 235).

A lover of neologisms (he invented the nowcommon words, "codification," "minimize," "maximize," and "international"), Bentham made a number of innovative proposals for concrete legal and social reform, including what he called a Pannomion 
(a complete and systematic code of laws that would leave no room for unreliable guesswork by citizens or arbitrary discretion by judges) and a Panopticon (a building whose design included a central observation tower allowing authorities at prisons, asylums, schools, and workhouses to see all of their charges all at once, without in turn being seen). In 1794, the English Parliament agreed to fund Bentham's Panopticon plan for a new prison, to be managed by Bentham himself (foundations for the prison were laid, but in 1804, the project was terminated on account of insufficient funding). Bentham's thought exerted a substantial influence over the later utilitarian and social reformist philosophies of James Mill (1773-1836), John Stuart Mill (1806-73), Henry Sidgwick (1838-1900), and Alexander Bain (1818-1903). Bentham's positivistic jurisprudence helped to inspire the later legal positivism of John Austin (1790-1859), Oliver Wendell Holmes, Jr. (1841-1935), Hans Kelsen (1881-1973), H. L. A. Hart (1907-92), and Joseph Raz (1939-). Bentham's utilitarian jurisprudence is the distant precursor to the "law and economics" school of contemporary legal theory, championed in its early days by Ronald Coase (1910-), Guido Calabresi (1932-), and Richard Posner (1939-).

\section{Immanuel Kant}

For Immanuel Kant (1724-1804), theorizing about the law cannot be based simply on our experientially derived judgments about human desires or needs since our merely empirical judgments can never yield the necessity and universality that are the true hallmarks of a genuine science of right. Instead, jurisprudence must take its bearings from the nonempirical or a priori concept of "right" (Recht) as such. According to its pure or a priori concept, "right" is the sum of the conditions under which the free choice of one person can be united with the free choice of others in accordance with a universal law. The "universal law of right" stipulates that persons may rightfully perform external actions only to the extent that the exercise of their free choice through such actions can coexist with the free choice of everyone else in accordance with a universal law. For Kant, the concept of right is necessarily connected with the authorization to use force or coercion (e.g., through the use of law). For a person acts wrongly when he or she hinders the free choice of someone else. Such a hindrance amounts to an act of coercion by the wrong-doer; for when the wrongdoer hinders the freedom of another, the wrongdoer forces the wronged party to do or refrain from doing something entirely apart from the wronged party's own act of choosing. Now if one person's use of freedom amounts to an act of hindering the freedom of another, then the use of coercion to prevent such a hindrance (the hindering of a hindrance to freedom or the coercive prevention of coercion) is justified.

Prior to Kant's time, it was common to think that the coercion of free persons by means of the law was justifiable on the grounds that freedom must be limited or compromised at times for the sake of achieving goods that are external to freedom itself. These goods might include the cultivation of individual virtue or the promotion of social welfare. Kant, however, rejects such an approach. For Kant, it is always wrong to coerce free persons for the sake of promoting goods that are external to freedom itself; for it is always wrong to use a person as a mere means to some end, even if the end for which the person is being used is an exceedingly important one. Significantly, Kant observes that what is right or justified does not pertain to relations between persons and external objects; it pertains instead to relations among persons. Although one person may never rightfully be used as a mere means for another person's ends, there is nothing about external objects as such that makes it wrong for persons to use them as mere means in the service of the ends that they freely set for themselves. Furthermore, free persons must be permitted to make use of external objects even when the objects being used are not in the spatial vicinity, or under the physical control, of the persons making use of them. Just as there is nothing about external objects as such that makes it wrong for persons to use them as means in the service of the ends that they freely set for themselves, so too there is nothing about the merely contingent empirical conditions of such objects (e.g., the merely contingent fact that the object exists in a certain spatial location or beyond the scope of a person's physical control over it) that can legitimately prohibit them from being used by persons in the service of their ends.

For Kant, in other words, it is necessary that persons be permitted to make use of external objects, not only through their empirical possession of such objects, but also through what Kant calls their 
intelligible or noumenal possession of them. To have intelligible possession of an external object, says Kant, is to have possession of it even when the person who possesses the object is not spatially adjacent to or physically in control of the object being possessed. Significantly, Kant argues that such intelligible possession of objects cannot be secured in a state of nature. For in a state of nature, says Kant, there is no generally accepted public authority for determining how the intelligible possession of external objects is to be acquired, enforced, and arbitrated in cases of disagreement. As a result, a person's ability to make use of an external object in a state of nature is forever insecure, dependent always on merely contingent empirical conditions, such as whether the person is strong, smart, or lucky enough to keep the external object from being appropriated and used by others. But this is just to say that in a state of nature, all possession is something other than rightful possession.

For Kant, persons are obliged to exit the state of nature and enter into a civil condition, or a "condition of right" under the rule of law. They are obliged to do so, not because doing so will help them to secure ends that are external to freedom itself (e.g., the ends of cultivating individual virtue or promoting of social welfare). Instead, argues Kant, free persons are obliged to live in a civil condition (and, incidentally, obliged not to destroy this civil condition by means of revolution) since it is only in a civil condition that they can fulfill their vocation as free persons; for it is only in a civil condition that they can rightfully make use of external objects in pursuing the ends that they freely set for themselves. For Kant, the aim of the law is to make possible the conditions of free personhood as such, and not to promote ends that are external to free personhood. Kant's theory of law thus stands opposed to all "welfarist" or "utilitarian" conceptions of the law. Kant's jurisprudential thought, with its emphasis on the importance of free personhood (and the relative unimportance of promoting individual virtue or social welfare), has influenced several twentieth-century jurisprudential thinkers. The most famous of these thinkers, including some who depart in one way or another from Kant's strict a priori, anti-welfarist theory of right, are John Rawls (1921-2002), Robert Nozick (1938-2002), Ronald Dworkin (1931-), and T. M. Scanlon (1940-).
Friedrich Carl von Savigny (1779-1861) was an early admirer of Kant, but inspired by post-Kantian Romanticism, he ended up rejecting what he regarded as the overly rationalistic, unhistorical character of Kantian jurisprudence. As a leading proponent of the German "historical school" of jurisprudence, Savigny went on to argue that the nature and origins of "right" should be understood not by reference to any nonempirical or a priori concept but by reference to the historically situated, empirically accessible Volksgeist, or "spirit of a people." Another early follower of Kant, Georg Wilhelm Friedrich Hegel (1770-1831), sought to develop a theory of law that would correct both the overly rationalistic character of Kantian jurisprudence as well as the overly empiricist character of Savigny's "historical" approach. According to Hegel, Kant erred by failing to realize that the abstract, free personhood with which he began his "science of right" was not the pure, unhistorical personhood that he took it to be but instead only the result of a long, historical process of self-transformation through labor and social interaction. If Kant had understood the underlying logic of human self-transformation through labor and social interaction, he would not have been so firmly committed to the false and dualistic belief that the law's purpose can be only to make possible the conditions of free personhood, and not to promote social welfare. Karl Marx (1818-83) famously developed Hegel's thought to argue that the dynamics of labor and social interaction not only make possible free personhood and legality as they exist but also will bring about social revolution and emancipation in the future. Until that occurs, says Marx, law will continue to serve as an ideological instrument for the oppression of one economic class by another. In the twentieth century and beyond, Marx's ideological-critical assessment of the law has been adopted and transformed by many different legal theorists (e.g., proponents of critical legal studies, critical race theory, and feminist legal theory) who have argued that the law can serve in various ways as an ideological instrument for oppressing persons on the basis of class, race, and gender.

Michael Baur

See also Bentham, Jeremy; Eighteenth-Century Political

Thought; Hegel, Georg Wilhelm Friedrich;

International Law; Justice; Kant, Immanuel; Marx, Karl; Montesquieu, Baron de; Natural Law; 
Nineteenth-Century Political Thought; Obedience, Political; Political Philosophy and Political Thought; Rawls, John; Rights, Natural and Human; TwentiethCentury Political Thought; Utilitarianism

\section{Further Readings}

Bentham, Jeremy. 1843. "Truth versus Ashhurst; Or, Law As It Is, Contrasted With What It Is Said To Be (1792)." In The Works of Jeremy Bentham, Vol. 5, edited by John Bowring, 231-37. Edinburgh: William Tait.

-1970. An Introduction to the Principles of Morals and Legislation. Edited by J. H. Burns and

H. L. A. Hart. London: Athlone Press. 1977. A Comment on the Commentaries and a

Fragment on Government. Edited by J. H. Burns and $\mathrm{H}$. L. A. Hart. London: Athlone Press.

Blackstone, William. 1765-69. Commentaries on the Laws of England. 4 vols. Oxford, UK: Clarendon Press.

Hegel, G. W. F. 1991. Elements of the Philosophy of Right. Translated by H. B. Nisbet and edited by Allen W.

Wood. Cambridge, UK: Cambridge University Press.

Kant, Immanuel. 1996a. The Metaphysics of Morals.

Translated and edited by Mary Gregor. Cambridge, UK: Cambridge University Press.

- 1996b. Practical Philosophy. Translated and edited by Mary J. Gregor. Cambridge, UK: Cambridge University Press.

Montesquieu, Baron de. 1989. The Spirit of the Laws. Translated and edited by Anne M. Cohler, Basia Carolyn Miller, and Harold Samuel Stone. Cambridge, UK: Cambridge University Press.

\section{Lefort, Claude}

Claude Lefort (1924-2010) played a major role in the revival of French political philosophy in the 1970s and 1980s. As a youth in Paris during World War II, Lefort studied with the philosopher Maurice Merleau-Ponty, whose phenomenological approach deeply influenced Lefort's political thought. In the early 1940s, Lefort was briefly involved with Trotskyist groups, but he quickly grew critical. With Cornelius Castoriadis, Lefort initiated a break from Trotskyism that led to the founding of the group and journal Socialisme ou Barbarie in 1948. As a member of this ultra-left libertarian group, Lefort opposed not only the Soviet Union and the French Communist Party but also fellow travelers like Jean-Paul Sartre. After years of fraught relations with Castoriadis, Lefort left Socialisme ou Barbarie in the early 1960s over disagreements about the nature and role of militant politics. Parallel to his political engagements, Lefort pursued a university career, teaching at several universities until his election to the prestigious École des Hautes Études en Sciences Sociales in 1976. In 1971, he completed a massive dissertation on Niccolò Machiavelli under the supervision of Raymond Aron. His preferred writing form is the essay, and many of his important texts are translated into three volumes, The Political Forms of Modern Society: Bureaucracy, Democracy, Totalitarianism; Democracy and Political Theory; and Writing: The Political Test.

A long-term critic of totalitarian regimes, Lefort gained prominence as a theorist of liberal democracy in the 1970s when many French intellectuals grew disillusioned with communism and Marxism more generally. Lefort's mature thought centers on three major claims. First, the proper goal of political philosophy is not to understand "politics" as a particular sector of social life but to explore the "political," which he defines as the basic framework that operates as the formative or generative principle of the social experience itself. Second, this framework is a symbolic construct: In contrast to Marxists, who would argue that power rests on a base of material relations, Lefort maintains that power functions only through representation. Third, and again in contrast to Marxism, division and conflict are ineradicable dimensions of social experience.

Lefort's work is best seen not as an attempt to provide liberal democracy with new or renewed normative foundations but as an effort to identify the formative principles of democratic pluralism. This search leads him back to a basic position advanced by Alexis de Tocqueville: What is most important about democracy is not what it does, but what it causes to be done, namely, its power to arouse constant agitation in people. Democracy's core lies not in a particular set of institutions acting in a certain way but in the open, indeterminate, and unmasterable process that democracy generates. Lefort traces this power of democracy to a "symbolic mutation" in the order of power. Earlier forms of society sought to conceal or overcome conflict through symbolic representations of power as a unity; so, for example, the early modern monarch symbolically incarnated the body politic in the unity of his or her body. In the struggle against monarchy climaxing in the French 
Revolution, power underwent a radical disincorporation in the name of egalitarian social relations. In Lefort's famous formulation, the symbolic center of modern democratic power is a lieu vide, an empty place. Democratic power may be contested, and specific people exercise power. However, no one can permanently appropriate or incarnate democratic power, nor can such power be definitively represented. Democracy is, therefore, not a regime governed by fixed laws or an unquestioned legitimate power. Rather, it is a regime based on the legitimacy of a debate as to what is legitimate; and this debate is without any final guarantor or terminus. Totalitarianism is, in Lefort's view, the modern counterpart of democracy because regimes like Nazism or Stalinism tried once again to conceal social division by reinvesting power in the symbol of the Nation, Party, Race, or Leader. Liberal democracy, by contrast, is an original form of society in which social division is the essence of its political logic. Once the markers of certainty that situated people in relation to each other have been lost, the conflict of opinion and the debate over rights become interminable.

Basing his thought on the collapse of transcendent sources of political legitimacy, Lefort created an original and highly influential theory of democracy, which illuminates the nature of sovereignty, the role of symbolic representation in politics, and the dynamic expansion of civil and human rights in the modern democratic era.

\section{Warren Breckman}

See also Communism, Varieries of; Democratic Theory; French Political Thought; Marx, Karl; Tocqueville, Alexis de; Totalitarianism; Twentieth-Century Political Thought

\section{Further Readings}

Breckman, Warren. Forthcoming. Adventures of the Symbolic: Postmarxism and Democratic Theory. New York: Columbia University Press.

Flynn, Bernard. 2005. The Pbilosophy of Claude Lefort: Interpreting the Political. Evanston, IL: Northwestern University Press.

Howard, Dick. 2002. The Specter of Democracy.

New York: Columbia University Press.

Moyn, Samuel. Forthcoming. A New Theory of Politics: Claude Lefort and Company in Contemporary France. New York: Columbia University Press.

\section{LEGITIMACY}

In the political context, legitimacy amounts to the governed recognizing the right of the governors to lead and, to a certain extent, their entitlement to the perks of power. It is a process through which both political power and obedience are justified. Yet, it is not as if the recognition of the right to govern is without constraints on those who govern. Conditions have to be met for the acknowledgment and justification of the right to govern-that is, for legitimacy-to develop. Three come to mind: First, those in power must deliver services to the governed. These services may vary from one society to another, from one period to another, but they are requirements that cannot be overlooked. Second, the services provided have to respond to and reasonably satisfy the key needs (of which security is an essential one) of the governed. These needs are themselves associated with the sense of the possible and the values (and the expectations they create) that are constitutive of the identity of society. As such, they are crystallized in the rights of people. Third, the needs/ rights benchmark the responsibility and accountability of those in the position of command as well as of that of the political institutions, including the procedures of exercise of power and of how they oversee the general arrangements of society.

The emergence of democratic values in the second half of the eighteenth century and their increasing importance ever since have emphasized these elements as central aspects of modern political legitimacy. Today the perception of political legitimacy comes down to the distribution of power being seen as expressing, defending, and promoting justice, understood as the fair allocation of, and access to, resources and opportunities (political, but also legal, economic, cultural, and others) resulting from relevant actors, with the attribution of rights and duties that comes with it. In this perspective, when political leaders and institutions, and the social system they underwrite, are viewed as unjust, and consequently illegitimate, it is not surprising that challenging social injustice and the political order becomes one and the same thing.

Authority being defined as legitimate power, and thus distinct from naked coercion, two contrasting dynamics of authority can be identified throughout history. First, when the legitimacy of leaders and 